\title{
Potential Use of SSR and ISSR Markers in Estimation of DNA Polymorphism Within Genus Vicia
}

\author{
Dragana Rajković · Ksenija Taški-Ajduković · Nevena Nagl • Milada Isakov • \\ Dragan Milić · Đura Karagić · Aleksandar Mikić
}

\begin{abstract}
Summary: The development of novel markers usually requires high costs and is time consuming. Instead of developing new markers, their transfer within a genus is an alternative particularly suitable in less studied species. Hence the goal of this study was to evaluate the ability of SSR markers, previously developed from Vicia faba, and ISSR markers to estimate DNA polymorphism within the genus Vicia. Eight Vicia species were used for cross-species amplification. Transferability of SSR markers in the studied species ranged from $25 \%$ to $100 \%$, with an average of 56.25\%. Although three SSR primers were polymorphic, the nature of the amplification products indicated that their further usefulness is questionable. ISSR primers generated polymorphic products of amplification in all tested Vicia species. The average polymorphism of ISSR primers was $93.75 \%$, which implies that these primers can be used within the genus Vicia.

Keywords: DNA polymorphism, ISSRs, molecular markers, SSRs, Vicia
\end{abstract}

\section{Introduction}

The genus vetch (Vicia L.) belongs to one of the largest families of flowering plants, Fabaceae (Leguminosae). It comprises a large and certainly not a definite number of species, presently estimated at more than 200 (ILDIS, 2005). Vetches are herbaceous annual and perennial species spread out in temperate zones of Euro-Asia, North and South America and Africa (Maxted 1995). They are known as food and forage legumes.

Regarding world production of 3.5 million tons (FAOSTAT, 2013), faba bean (Vicia faba) is categorized as the most important species in the Vicia genus, while in Serbia it is grown only locally (Mihailović et al. 2005). Common vetch (Vicia sativa L.), hairy vetch (Vicia villosa Roth), Hungarian vetch (Vicia pannonica Crantz), Narbonne vetch (Vicia narbonensis L.) and bitter vetch (Vicia ervilia L.) are grain legumes commonly used as forage (Jaiwal \& Singh 2003). In Serbia, vetches are grown on the area of around 7,000 ha (Mikić et al. 2006) with average yield $1,200 \mathrm{~kg} / \mathrm{ha}$ (Karagić et al. 2010). Vicia sativa L., Vicia villosa Roth and Vicia pannonica Crantz are economically most important vetches grown on

D. Rajković · K. Taški-Ajduković* · N. Nagl · M. Isakov · D. Milić · Đ. Karagić · A. Mikić

Institute of Field and Vegetable Crops, 30 Maksima Gorkog, 21000 Novi Sad, Serbia

e-mail: ksenija.ajdukovic@nsseme.com
Serbian fields (Vujaković et al. 2011). Certain Vicia species are also used as cover crops, green manure or livestock forage (Allen \& Allen 1981).

There are about 30 species of vetches in the Serbian flora. Recently it has been demonstrated that some of these, such as narrow-leaved vetch $(V$. sativa ssp. nigra L.) and large-flowered vetch ( $V$. grandiflora L.), have considerable potential for agricultural production (Ćupina et al. 2007). Beside high forage yields, $V$. grandiflora possesses some preferences, such as tolerance to low temperatures and earliness, allowing it to fit well into any model of crop rotation (Mikić et al. 2008).

SSRs (simple sequence repeats) are abundant, codominant, reproducible markers with great genome coverage (Kalia et al. 2011). SSR analysis has not been used extensively for molecular studies of species that lack information on DNA sequence because of the high costs of development. Thus, markers from well-studied species can be used in species with no, or low amount of available molecular data. Inter simple sequence repeat (ISSR) is fast and simple PCR-based method that amplifies sequences located between two microsatellite regions. They are not sequence-specific and amplify

\footnotetext{
Acknowledgements: This study was funded by the Ministry of Education, Science and Technological Development of the Republic of Serbia through the project "Increasing market significance of forage crops by breeding and optimizing seed production technology" (TR 31024).
} 
sequences of 200-2000 bp in length (Pradeep Reddy et al. 2002). Although only one primer of 16-25 bp in length is used (Zietkiewicz et al. 1994), ISSRs proved to be stable and reproducible (Bornet \& Branchard 2001).

So far, DNA markers like RAPDs, ISSRs, AFLPs and SSRs were extensively used in assessing genetic diversity in faba bean (Link et al. 1995, Zeid et al. 2003, Román et al. 2004, Wang et al. 2012), while in common vetch only few studies were published (Potokina et al. 2000, 2002, Raveendar et al. 2015). There is low amount of available information considering molecular markers in other species within the Vicia genus. The above mentioned is the reason why possibility of transferring markers from closely related species was exploited in this study. The aim of this study was to investigate the possible use of previously developed SSR markers from Vicia faba and ISSR markers used in three Vicia species ( $V$. ramuliflora, $V$. unijuga and $V$. cracca) in estimation of DNA polymorphism within the genus Vicia.

\section{Materials and Methods}

Eight Vicia species were used in this study. Six species, each with three accessions, were taken from the Institute of Field and Vegetable Crops vetch collection: Vicia villosa, Vicia pannonica, Vicia ervilia, Vicia faba, Vicia narbonensis and Vicia sativa ssp. sativa. Samples of Vicia grandiflora were collected at localities in Novi Sad, Kruševac and Belgrade, while Vicia sativa ssp. nigra samples were collected at Arhangel (Macedonia), and two localities in Novi Sad.

Leaves from single plant were used for Vicia grandiflora and Vicia sativa ssp. nigra DNA isolation from every locality. Genomic DNA from other Vicia species was isolated from approximately $25 \mathrm{~g}$ of seed bulk from every accession. Total DNA was extracted using Nucleo Spin Plant (Machery-Nagel) kit. DNA concentration was estimated by visualization on $1 \%$ agarose gels in $0.5 x$ TBE buffer with ethidium bromide $(0.5 \mathrm{~g} / \mathrm{ml})$ added to the gel. The $\lambda$ phage DNA concentrations of $25 \mathrm{ng}, 50 \mathrm{ng}, 100 \mathrm{ng}$ and 250 ng were used as standards. Images were taken under UV light.

A set of three SSR markers (VfG7, VfG14, VfG24) from Vicia faba was selected for the analysis, since they were known to have amplification products in at least one of five European genotypes (Zeid et al. 2009). Another three SSRs (GA4, GAI1, GATA5) were chosen from Požárková et al. (2002) because of the large number and size of their repeat motifs. SSR primer sequences are listed in Table 1 . In order to amplify reaction product, polymerase chain reaction (PCR) was performed in volume of $25 \mu \mathrm{l}$, containing $1 \times$ PCR buffer (Thermo Scientific, including $20 \mathrm{mM}$ $\mathrm{MgCl}_{2}$ ), $0.2 \mathrm{mM}$ each dNTP (Thermo Scientific), 0.4 $\mu \mathrm{M}$ primer (Thermo Scientific), 1.5 U Dream Taq DNA polymerase (Thermo Scientific) and 50-100 ng DNA. Tpersonal thermocycler (Biometra) was used for DNA amplification. Touchdown program was applied to amplify GA4, GAI1 and GATA5 primers. After initial denaturation at $95^{\circ} \mathrm{C}$ for $3 \mathrm{~min}$ and denaturation at $95^{\circ} \mathrm{C}$ for $50 \mathrm{~s}$, annealing was performed during $30 \mathrm{~s}$ at $68^{\circ} \mathrm{C}$ for $\mathrm{GA} 4,65^{\circ} \mathrm{C}$ for GAI1 and $66^{\circ} \mathrm{C}$ for GATA5. Primer extension lasted $1 \mathrm{~min}$ at $72^{\circ} \mathrm{C}$. Annealing temperatures decreased for $1^{\circ} \mathrm{C}$ per cycle until reaching final annealing temperatures $\left(62^{\circ} \mathrm{C}, 55^{\circ} \mathrm{C}\right.$ and $58^{\circ} \mathrm{C}$ for GA4, GAI1 and GATA5, respectively). After reaching final annealing temperature, amplification ran for another thirty cycles for GAI1 and 35 cycles for GA4 and GATA5. Final elongation was done at $72^{\circ} \mathrm{C}$ for 10 min. PCR conditions for VfG7, VfG14 and VfG24 primers included: initial denaturation at $95^{\circ} \mathrm{C}$ for 4 min, 30 cycles of denaturation at $95^{\circ} \mathrm{C}$ for $45 \mathrm{~s}$, annealing at $50^{\circ} \mathrm{C}$ for $60 \mathrm{~s}$ and elongation at $72^{\circ} \mathrm{C}$ for $60 \mathrm{~s}$. In the end, final elongation was performed at $72^{\circ} \mathrm{C}$ for $7 \mathrm{~min}$.

Table 1. SSR primers used for cross-species transferability testing within Vicia genus

\begin{tabular}{|c|c|c|c|c|}
\hline Primer & Forward primer sequence & Reverse primer sequence & Repeat motif & $\begin{array}{c}\text { Expected } \\
\text { size (bp) }\end{array}$ \\
\hline VfG7 & AGGCATGTGGTGTTTTGATT & GCAATAAAATATGCTTTTCTGGA & $(\mathrm{AG})_{12}$ & 284 \\
\hline VfG14 & CAAGCTTGTTGAGAGCCAAA & GAACGAGGCTCACGAAAATA & $(\mathrm{AG})_{10}$ & 229 \\
\hline VfG24 & GTGTCATCGACCACATGGTTA & CAGCTGAGCACGAGACTAA & $(\mathrm{AG})_{9}$ & 273 \\
\hline GA4 & GAACTAAGGTGTACACGCGGG & GGGGGGTAGATCTTGTTTTTTTCC & $(\mathrm{CT})_{16}$ & 232 \\
\hline GAI1 & GTTGAGGCAGGTTAGGAGGG & GTTTGCCAGTTACT'TTGTTCACG & $(\mathrm{GA})_{14}$ & 242 \\
\hline GATA5 & GAAACGTGCCTATGTAAAGGGA & GAATCTGATTCTGCTCAAAAGCA & $(\mathrm{GATA})_{2} \mathrm{GGT}(\mathrm{GATA})_{6}$ & 291 \\
\hline
\end{tabular}


Table 2. ISSR primers used for testing DNA polymorphism within Vicia genus

\begin{tabular}{ll}
\hline Primer & Primer sequence \\
\hline $\mathbf{( G A C A}_{4}$ & GACAGACAGACAGACA \\
$(\mathbf{A G})_{8} \mathbf{T}$ & AGAGAGAGAGAGAGAGT \\
$\mathbf{( A C )})_{8} \mathbf{T}$ & ACACACACACACACACT \\
$(\mathbf{G A})_{8} \mathbf{T}$ & GAGAGAGAGAGAGAGAT \\
\hline
\end{tabular}

Amplified fragments were separated on $2 \%$ agarose gel containing ethidium bromide $(0.5 \mathrm{~g} / \mathrm{ml})$ and visualized under UV light. GeneRuler $50 \mathrm{bp}$ DNA Ladder and O'RangeRuler 200 bp DNA Ladder (Termo Scientific) were used as molecular standard.

Four ISSR markers (Table 2) that proved to give clear polymorphic bands in three Vicia species (Vicia ramuliflora, $V$. unijuga, $V$. cracca) were chosen (Han \& Wang 2009). For each reaction 50-100 ng DNA was used, with $10 \mathrm{x}$ reaction buffer (Thermo Scientific, including $20 \mathrm{mM} \mathrm{MgCl} 2$ ), $0.2 \mathrm{mM}$ of each dNTP, 0.2 $\mu \mathrm{M}$ primer (Metabion international ag) for $(\mathrm{AG})_{8} \mathrm{~T}$, $(\mathrm{AC})_{8} \mathrm{~T}$, and $2 \mu \mathrm{M}$ for $(\mathrm{GACA})_{4}$ and $(\mathrm{GA})_{8} \mathrm{~T}, 1.5 \mathrm{U}$ Dream Taq polymerase. PCR was performed as follows: 1 cycle for $3 \mathrm{~min}$ at $94^{\circ} \mathrm{C}, 35$ cycles of $92^{\circ} \mathrm{C}$ for $30 \mathrm{~s}, 50^{\circ} \mathrm{C}\left(55.2^{\circ} \mathrm{C}\right.$ for $\left.(\mathrm{AC}){ }_{8} \mathrm{~T}\right)$ for $30 \mathrm{~s}$ and $72^{\circ} \mathrm{C}$ for $1 \mathrm{~min}$, followed by 1 cycle for $5 \mathrm{~min}$ at $72^{\circ} \mathrm{C}$.

Products of ISSR marker amplification were separated on $1.5 \%$ agarose gels. Ethidium bromide $(0.5 \mathrm{~g} / \mathrm{ml})$ was used to make bands visible under UV light. 200 bp O`Range Ruler (Termo Scientific) was utilized as molecular standard.

Bands were analysed visually in order to observe whether the amplification occurred. SSR bands were scored with "+" for amplicons of different size then in Vicia faba, "(+)" for amplicons of the same size as in Vicia faba and "-" for no amplification. ISSR banding patterns of Vicia sp. were compared with each other and marked as "+" for different banding patterns and " $(+)$ " for the same banding patterns.

\section{Results and Discussion}

This study evaluated the ability of SSR markers from $V$. faba to amplify in other Vicia species and possible use of ISSRs in Vicia sp. was investigated. Four out of six SSR primers generated amplification products in $V$. faba of the same size as in Zeid et al. (2009) and Požarkova et al. (2002) (Table 3). Although $V$. faba in the study did not amplify with VfG24, the size of products obtained in $V$. sativa ssp. nigra and $V$.grandiflora was as expected in $V$. faba. The same was with $V$.grandiflora's amplification product with primer GATA5. Amplification products GA4, and GAI1 in all Vicia species were monomorphic, except in $V$. sativa ssp. nigra. Therefore, these primers could not be considered suitable for further variability studies in Vicia genus. Amplification products of primers VfG7, VfG14 and GATA5 were polymorphic, but their poor quantity and quality calls their usefulness into question.

Primer VfG14 amplified in all tested species (Figure 1), while GAI1 primer amplified with success rate of $75 \%$. Primer GATA5 amplified DNA of $62.5 \%$ tested Vicia sp. The lowest amplification was observed for VfG24 primer, which generated products only in $V$. sativa ssp. nigra and $V$. grandiflora. Average transferability of SSR markers was $56.25 \%$ which was in concordance with the previously published results on legumes (Reddy et al. 2010, Datta et al. 2012, Gupta et al. 2013).

Table 3. Transferability of SSR primers within Vicia genus

\begin{tabular}{lcccccc}
\hline Vicia sp & VfG7 & GA4 & VfG14 & GAI1 & VfG24 & GATA5 \\
\hline Vicia faba* & $290 \mathrm{bp}$ & $230 \mathrm{bp}$ & $230 \mathrm{bp}$ & $240 \mathrm{bp}$ & - & - \\
Vicia narbonensis & + & $(+)$ & + & $(+)$ & - & + \\
Vicia ervilia & + & $(+)$ & + & $(+)$ & - & + \\
Vicia pannonica & - & - & $+/-$ & - & - & - \\
Vicia villosa & - & - & $+/(+)$ & - & - & - \\
Vicia sativa ssp. sativa & - & - & + & $(+)$ & - & + \\
Vicia sativa ssp. nigra & + & $(+)$ & + & + & $(+)$ & + \\
Vicia grandiflora & - & - & + & $(+)$ & $(+)$ & $(+)$ \\
Transferability (\%) & 50 & 50 & 100 & 75 & 25 & 62,5 \\
\hline
\end{tabular}

* observed product size, + different size than in V. faba, $(+)$ same size as in V. faba, - no amplification 


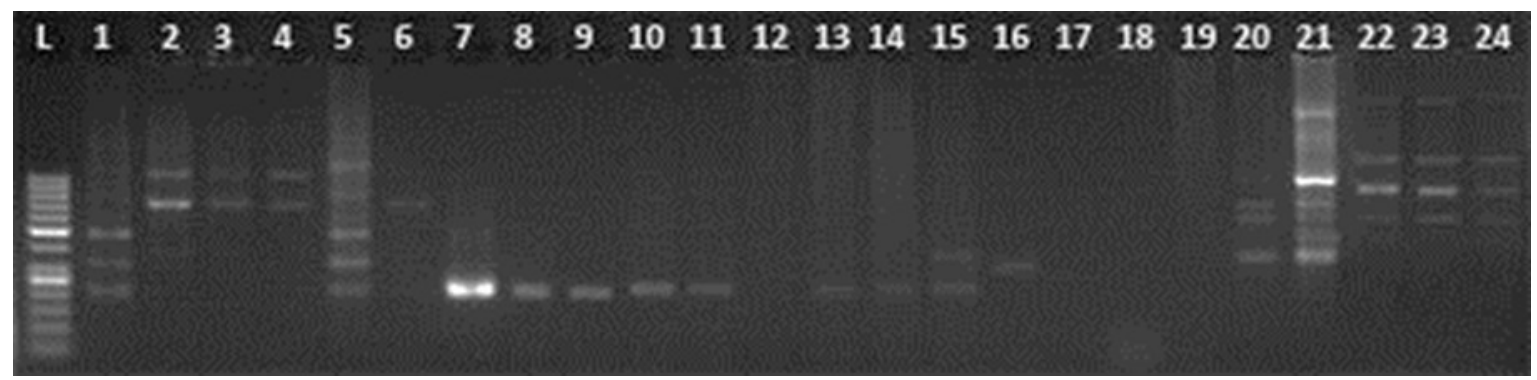

Figure 1. Amplification products with primer VfG14 in Vicia sp. (L-50bp ladder, 1, 2, 3-V. narbonensis, 4, 5, 6-V. ervilia, 7, 8, 9$V$. faba, 10, 11, 12-V. pannonica, 13, 14, 15-V. villosa, 16, 17 18-V. sativa ssp. sativa, 19, 20, 21 - V. grandiflora, 22, $23,24-V$. sativa ssp. nigra)

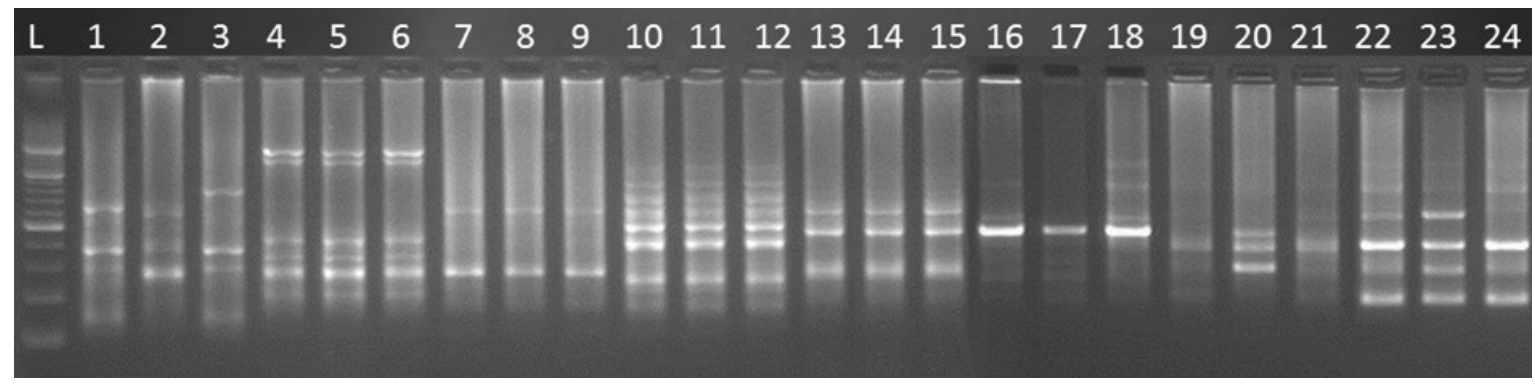

Figure 2. Amplification products with primer (AC) $8 \mathrm{~T}$ in Vicia sp. (L-200bp ladder, 1, 2, 3-V. narbonensis, 4, 5, 6-V. ervilia, 7, 8, 9-V.faba, 10, 11, 12-V.pannonica, 13, 14, 15-V. villosa, 16, 17 18-V. sativa ssp. sativa, 19, 20, 21-V. sativa ssp. nigra, 22, 23, 24V. grandiflora)

Table 4. Polymorphism of ISSR primers in Vicia genus

\begin{tabular}{|c|c|c|c|c|}
\hline Vicia $s p$ & $\begin{array}{c}\text { (GAC } \\
\text { A) }{ }_{4}\end{array}$ & $\begin{array}{c}\text { (AG) } \\
{ }_{8} \mathrm{~T}\end{array}$ & $\begin{array}{c}\text { (AC) } \\
8 \mathrm{~T}\end{array}$ & $\begin{array}{c}(\mathrm{GA}) \\
8 \mathrm{~T} \\
\end{array}$ \\
\hline Vicia narbonensis & + & + & + & $(+)$ \\
\hline Vicia ervilia & + & + & + & + \\
\hline Vicia faba & + & + & + & $(+)$ \\
\hline Vicia pannonica & + & + & + & + \\
\hline Vicia villosa & + & + & + & + \\
\hline $\begin{array}{l}\text { Vicia sativa ssp. } \\
\text { sativa }\end{array}$ & + & + & + & + \\
\hline $\begin{array}{l}\text { Vicia sativa ssp. } \\
\text { nigra }\end{array}$ & + & + & + & + \\
\hline Vicia grandiflora & + & + & + & + \\
\hline Polymorphism (\%) & 100 & 100 & 100 & 75 \\
\hline
\end{tabular}

+ different banding patterns, $(+)$ same banding patterns

All tested ISSR primers generated different amplification profiles in Vicia sp. (example in Figure 2), with exception of Vicia narbonensis and Vicia faba, which had the same banding pattern with primer $(\mathrm{GA})_{8} \mathrm{~T}$ (Table 4). The average polymorphism of ISSR primers was very high $(93.75 \%)$, confirming results that this type of markers could be useful in species differentiation and diversity studies in Vicia sp.

\section{Conclusions}

The development of novel markers usually requires high costs and is time consuming. Instead of developing new markers, their transfer within genus could be alternative, particularly suitable in less studied species. In this study we assessed the potential for cross-species amplification of SSR markers developed from Vicia faba. Although primers VfG7, VfG14 and GATA5 were polymorphic, quantity and quality of the amplification products indicates that their usefulness in further variability studies is questionable. The conditions of amplification reactions would have to be extensively modified which could take a lot of time and resources. Therefore, it is our opinion that in variability studies of Vicia sp., some other approach should be considered, such as development of EST-based markers, which are easier and less expensive to develop and possess high rate of transferability to related species.

Within ISSR set, reactions resulted in different amplification profiles for each investigated Vicia species. Our results imply that these primers can be used within the genus Vicia. 


\section{References}

Allen, O. N. \& Allen, E. K. (1981). The Leguminosae, a source book of characteristics, uses, and nodulation. University of Wisconsin Press, USA.

Bornet, B. \& Branchard, M. (2001). Nonanchored Inter Simple Sequence Repeat (ISSR) Markers: Reproducible and Specific Tools for Genome Fingerprinting. Plant. Mol. Biol. Rep., 19: 209 -215 .

Ćupina, B., Krstić, D., Mihailović, V., Mikić, A. \& Vasiljević, S. (2007). Urban populations of vetches (Vicia spp.) have potential for forage yields. Bioversity International Newsletter for Europe, 34, 12.

Datta, S., Kaashyap, M., Singh, P., Gupta, P. P., Anjum, K. T., Mahfooz, S. \& Gupta, S. (2012). Conservation of microsatellite regions across legume genera enhances marker repertoire and genetic diversity study in phaseolus genotypes. Plant Breeding 131: 307-311.

FAOSTAT (2013). FAO Statistical Databases (FAOSTAT). Food and Agricultural Organization of the United Nations (FAO), Rome, http:// faostat.fao.org.

Gupta, S., Sen Gupta, D., Anjum, K.T., Pratap, A. \& Kumar, J. (2013). Transferability of simple sequence repeat markers in black gram (Vigna mungo L. Hepper), Aust. J. Crop Sci. 7: 345-353.

Han, Y. \& Wang, H. Y. (2009). Genetic Diversity and Phylogenetic Relationships of Two Closely Related Northeast China Vicia Species Revealed with RAPD and ISSR Markers. Biochem. Genet. 48, 385-401.

ILDIS (2005). ILDIS World Database of Legumes. International Legume Database \& Information Service (ILDIS), http:// www.ildis.org.

Jaiwal, P. K. \& Singh, R. P. (2003). Applied Genetics of Leguminosae Biotechnology. Kluwer Academic Publishers, London.

Kalia, R. K., Rai, M. K., Kalia, S., Singh, R. \& Dhawan, A. K. (2011). Microsatellite markers: An overview of the recent progress in plants. Euphytica 177: 309-334.

Karagić, Đ., Jevtić, G. \& Terzić, D. (2010). Forage legumes seed production in Serbia. Biotech. Anim. Husbandry 26 (spec.issue), 133-148.

Link W., Dixkens C., Singh M., Schwall M. \& Melchinger A. E. (1995). Genetic diversity in European and Mediterranean faba bean germplasm revealed by RAPD markers. Theor. Appl. Genet. 90: $27-32$.

Maxted, N. (1995). An ecogeographical study of Vicia subgenus Vicia, Systematic and Ecogeographic Studies on Crop Genepools, 8. International Plant Genetic Resources Institute, Rome, Italy.

Mikić, A., Ćupina, B., Katić, S. \& Karagić, Đ. (2006). Značaj jednogodišnjih krmnih mahunarki u obezbedivanju biljnih proteina. Zbornik radova Naúnog instituta za ratarstvo i povrtarstvo 42 (1): 91-103.
Mikić, A., Mihailović, V., Ćupina, B., Krstić, Đ., Hauptvogel, P., Hauptvogel, R., Vasić, M., Duc, G. \& Burstin, J. (2008). Genetic resources of vetches (Vicia spp.) in Serbia. Proc. Int. Conf. Conv. Mol. Breeding Field Veg. Crops, Novi Sad, Serbia, 121 127.

Mihailović, V., Mikić, A., Ćupina, B. \& Erić, P. (2005). Field pea and vetches in Serbia and Montenegro. Grain Legum. 44: 25-26.

Potokina, E., Vaughan, D. A., Eggi, E. E. \& Tomooka, N. (2000). Population diversity of the Vicia sativa agg. (Fabaceae) in the flora of the former USSR deduced from RAPD and seed protein analyses. Genet. Resour. Crop Evol. 47 (2): 171-183.

Potokina, E., Blattner, R., Alexandrova, T., \& Bachmann, K. (2002). AFLP diversity in the common vetch (Vicia sativa L.) on the world scale. Theor. Appl. Genet. 105 (1): 58-67.

Požárková, D., Kobližková, A., Román, B., Torres, A. M., Lucretti, S., Lysák, M., Doležel, J. \& Macas, J. (2002). Development and characterization of microsatellite markers from chromosome 1specific DNA libraries of Vicia faba. Biol. plantarum 45 (3), 337345.

Pradeep Reddy, M., Sarla, N. \& Siddiq, E. A. (2002). Inter simple sequence repeat (ISSR) polymorphism and its application in plant breeding, Euphytica 128: 9-17.

Raveendar, S., Lee, G. A, Jeon, Y. A., Lee, Y. J., Lee, J. R., Cho, G. T., Cho, J. H., Park, J. H., Ma, K. H. \& Chung, J. W. (2015). CrossAmplification of Vicia sativa subsp. sativa Microsatellites across 22 Other Vicia Species, Molecules 20, 1543-1550.

Reddy, M. R. K., Rathour, R., Kumar, N., Katoch, P. \& Sharma, T. R. (2010). Cross-genera legume SSR markers for analysis of genetic diversity in Lens species, Plant Breeding 129, 514 -518.

Román, B. L., Satovic, Z., Pozarkova, D. D., Macas, J., Dolezel, J., Cubero, J. I. \& Torres, A. M. (2004). Development of a composite map in Vicia faba L., breeding applications and future prospects. Theor. Appl. Genet. 108: 1079-1088.

Vujaković, M., Jovičić, D., Karagić, D., Mikić, A., Nikolić, Z., Petrović, D. \& Taški-Ajduković, K. (2011). Indicators of Winter Vetch (Vicia spp.) Seed Vigor, Ratar. Pourt. 48: 131-136.

Wang, H. F., Zong, X. X., Guan, J. P., Yang, T., Sun, X. L., Ma, Y. \& Redden, R. (2012). Genetic diversity and relationship of global faba bean (Vicia faba L.) germplasm revealed by ISSR markers. Theor. Appl. Genet. 124 (5): 789-97.

Zeid, M. A., Schön, C. C. \& Link, W. (2003). Genetic diversity in recent elite faba bean lines using AFLP markers. Theor. Appl. Genet. 107: 1304-1314.

Zeid, M., Mitchell, S., Link, W., Carter, M., Nawar, A., Fulton, T. \& Kresovich, S. (2009). Simple sequence repeats (SSR) in faba bean: new loci from Orobranche-resistant cultivar 'Giza 402'. Plant Breeding 28 (2), 149-155.

Zietkiewich, E., Rafalski, A. \& Labuda, D. (1994). Genome Fingerprinting by Simple Sequence Repeat (SSR)-Anchored Polymerase Chain Reaction Amplification. Genomics 20, 176-183.

\section{Mogućnost primene SSR i ISSR markera u proceni DNK polimorfizma unutar roda Vicia}

\section{Dragana Rajković · Ksenija Taški-Ajduković · Nevena Nagl · Milada Isakov Dragan Milić · Đura Karagić · Aleksandar Mikić}

Sažetak: Razvoj markera obično zahteva vreme i velika materijalna ulaganja. Umesto razvijanja novih markera za manje proučavane vrste, alternativa može biti transfer sa vrsta unutar istog roda. Cilj ovog rada je bio da se proceni mogućnost primene SSR prethodno razvijenih na Vicia faba i ISSR prajmera u proceni DNK polimorfizma u rodu Vicia. Prenosivost SSR markera se kretala u intervalu 25-100\% sa prosečnom vrednošću od $56,25 \%$. Iako su produkti tri SSR prajmera bili polimorfni, zbog dobijene količine i kvaliteta, njihovo korišćenje u daljim istraživanjima je diskutabilno. Svi ispitivani ISSR prajmeri su davali različite profile amplifikacije za svaku ispitivanu vrstu. Prosečni procenat polimorfizma ISSR prajmera je bio vrlo visok (93,75\%), što sugeriše da ovi prajmeri mogu biti korišćeni u proceni DNK polimorfizma unutar roda Vicia.

Ključne reči: DNK polimorfizam, ISSR, molekularni markeri, SSR, Vicia 